\title{
LEGAL ETHICS
}

\section{w. F. Bowne*}

A profeasion differs from a trade because the main object of a trade is profit whale a profession, in Roscoe Pound's words is "a group of men pursuing a learned art as a common calling in the spirit of public service". A tradesman does not act on behalf of his customer, but the member of a profession does act on behali of those whom he serves. This special relationship between lawyer and elient or physician and patient is one of trust, calling for rules of conduct higher than those which the general law reguires of the ordinary cirizen. These rules may be calied the ethics of the profeasion.

To exphin "ethical conduct" it might help to describe "unechical conduct". The auchor of a recent American book on Legal Ethics, H. S. Drinker, says that unethical conduct, calling for disciplinary measures, comes under two headings (1) moral unfimess to advise and represent clients and (2) unworthiness to continue in the legal profeasion. This distinction seems helpful, though in some cases improper conduct may come under both headings.

In the legal profession, it is doubtful whether the ethical standards go back as far as the physician's oath of Hippocrates, but cerrainly in England they began to develop when atromeys and pleaders emerged in the reiga of Edward I. The medievelal attorney rook an outh to truly and honestly demean himself in the practice of an attorney, and the sergeane at law swore that he would serve well the King's people, counsel them truly and not defer or delay their causes for his own profit.

Since this paper will deal specifically with professional ethics in Canada, it may help to mention the differences in the organization of the profession in the two countries. In Canada professions are controlled by the provinces and the typical statute creates a law eociety whose members alone have the right to pracrice law and who are boch barristers and solicicors. They ase officers of the court, which an Englich barrister is not, and disciplinary power rests in the benchers of the sociery. The union of the two branches renders inapplicable some of the English rules which deal with the relationship between barristers, solicitors and the public. Most diecurcions of English ethieal standards dea! with the echics of advocacy, and the rules which appear from time to time in the Annual Practice are opinioas of the General Council, save for those relating to the secainer of barristers, which were framed jointly by the two branches of the profession. A practitioner in Canadn is subject to the rules governing both branches, but after making allowarces for the differences in organization in the two countries, it is correct to eay that the profession in Canada adopes the English standards. In each province bowever, come standards may be found ir. stanutes as well as in judgments and in cartom.

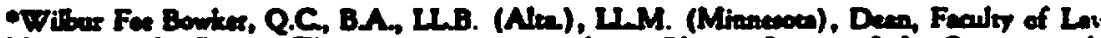

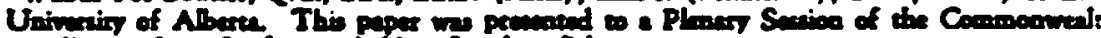
and Empire Low Conference beld in Loador, July, 1955. 
Moreover there exists in Canada written canons of Ethics of the Canadian Bar Association, a voluntary but influential body. In 1919 the asociacion decided to adopt Cenons, based on those of the American Bar Aseociation, and they were approved in 1920.

Some lawyers in Canada objected to the Canons on the ground that in England it has not been found necessary wo codify the echics of the profeasion, and also because there may be a danger that lawyers will treat them like a caxing stature that applies only where the individual comes within the letter of the law. The answer to this last objection is that the canons are nor exhaustive, but "should be construed as a general guide and not as a denial of the existence of other duries". As for the first objection, the English rules alrendy mentioned do constirute a partial codification, and in any case there are many differences between the two countries. In Canada there is no couterpart of the Inns of Court and instead of a small bar devoted exclusively to counsel work, there are ten provincial societies most of whose members (except in Quebee) are both barristers and solicitors, with divergent educational background, many of them living in scattered thinly populated areas and without the daily coneact with the courts that an English barrister enjoys. It is hard to see how the formulation of the Canons could fail to be beneficial. It is true that so fas as we have learned, the only law societies that officially adopted them were those of the western provinces. A short examination of the Canons will show however that subject to minot variations they conform to the high standards of the profession in England.

The Canadian canons are grouped under five headings - the lawyer's duty to the state, the court, his fellow lawyers, his client and himself. We do not propose to summarize the canons in order, but think it worthy of note that they are framed so as so emphasize the various duties of the lawyer, which of course put limits on each other duty. No lawyer should fall into the error of misinterpreting Lord Brougham's famous statement in Queen Caroline's case "that an advocate, by the sacred duty which he owes his client, knows in the dis. charge of that office, but one person in the world, that client, and no other." Lord Brougham did not mean that the advocate has no duty to the state, the court, or the profession, but rather that his duty to his client may require him to attack the character of other persons-in Queen Caroline's case, Ning George IV. However, one somerimes hears lawyers in conversation stress the obligation to the client as though this were the conly duty the lawyer owes.

Coming now to the contents of the canons, we shall mention first those selating to criminal cases. The primary duty of the prosecutor "is not to convict, but to see that justice is done" and he should withhold no facts tending in prove either the guilt or innocence of the accused. There is no ground for saying that generally Canadian prosecutors do not obeerve the English tradicion. The law reports disclose but a few inscances in which the courc has reproved Crown counsel for unfairness. The duty to withhold no relevant information has been laid down by the Privy Council, though in 1951 the Supreme Court of Canada held that there is no rigid rule that the Crown must call every person who ap. 
pears to know something of the facts or to tender him for cross-examination. The Crown has a discretion with which the Court will not interfere uniess 1: appears that the Crown exercised its discrecion "from some oblique motive".

The canons prescribe the duty to act on behalf of an accused person wher: asked in rine Court, and there are many instances in which this is done. However there is anorher canon which says that no lawyer is obliged to act either as advisor or advocare for every person who may wish to become his client. He has the rigits to decline employment. It may be pertinent to note that it is the general practice for the Crown to pay the fees of counsel for the accused in serious cases where he has no funds, and there has been a strong movement to ward serting up machinery in the law societies to provide legal aid for needy: persons though in most provinces where such provisions exist the aid is confined to civil cases.

In litigation generally the canons say that the lawyer's conduct should bo characterized by candour and fairness, courtesy and respect to the court and coustesy to the witness. The obligarion not to mislead the court was well put by the late Chief justace Anglin in 1909. "The court has the right to rely upon him to assist it in ascertaining the truth. He should be most careful to state with strict accuracy the contents of a paper, the evidence of a witness, the admissions or the argument of his opponert. Knowingly to cite an overruled case or to refer to a repealed statute as still in force, would be unpardonable. and counsel cannot be too cautious not to make such mistakes unwittingly".

One specific problem that is of great interest as a matter of ethics, though it does not arise of fen, is this - is counsel obliged to cite adverse authority? Now if the proceedings are ex parse it seems cleat that he is bound to do so: ordinarily however there is counsel on the other side and in nearly all cases he will have found the cases in his favour, or at least those that are binding or that originate in courts whose judgements have high persuasive authority. Assum. ing, however, that he has not, there is little discussion in Canada on the point but it seems clear from the English discussions such 25 those of Lord Mar. Millan and Mr. Justice Hilbery that although counsel is not obliged to arguc the other side's case he should not knowingly remain silent if he knows of a binding decision that is or appears to be unfavourable. There may be more de. bate if the case is not binding, but if he is asked if there is authority on the point, he must give it.

The other question that laymen never cease to ask, How do you justify the defence of a guilty man? is not really hard to answer. The canons say that counsel should endeavour by all fair and honourable means to obtain for his slient the benefit of every remedy and defence which is authorized by law, and also that it is his right to undertake the defence of a person accused of crims; regardless of his own personal opinion as to the guilt of the accused.

Laymen of course think that this is mere sophistry. Most of us in the proession are satisfied with the justification which Dr. Johnson gave almost two aundred years ago and with the streement of the General Council of the Bar in 1915 on the position of counsel where his client has confessed. In this case, the 
1915 ruling savs it is advisable to withdraw if the confession has been made before the acivocate has undertaken the defence; but that if it is made during the proceedings, then counsel should proceed, his duty being to see that his client is convicted only upon proper evidence, though of course he should not attempt to set up a defence such as an alibi. or to blame another for the crime.

Other durtes connected with trials are (1) not to offer evidence which the court should not admit (2) to treat adverse witnesses with fairness (3) not to express inis personal belief on matters of fact in dispute and (4) not to resrify in a case where he is counsel. No comment need be made on the first of these. As for the second, the Canadian canons do not expressly say that counsel should not asik questions affecting the witness's character merely to attack his credibilitv uniess he has reasunable grounds for believing they are true. This is the English rule and as far as 1 know understood to be the rule in Canada. As for the third this is doubrless observed by experienced counsel though one some. tunes hears counsel sav "I think the evidence. justifies a finding for the plaintiff" or "I believe my client innocent". As for the fourth, many cases arise in which the law'ver for a party withoraws as counsel where he knows beforehand that he wili he needed as a wirness.

The subject of fees is of course important. Indeed this is the one area in which che lawver's interest confliets with that of his client. The canons require him to ciarge neither less nor more than reasonable compensation, and where possible to adhere to establisined tariffs. He is recommended to avoid unseemly disputes nver his fees. In England of course a barrister may not sue for his ire but I knnw nt no such prohibition in Canada. The right of a client to rax his solicitor's arcounut is ot course a safeguard against exorbitant fees though the right is nor realiv of helo in small matters. Other important canons relatung to fees remind him that he must not stir up litigation for the purpose of seeking a retainer, and that "he should not, except as by law expressly sancrioned. arquire bv purchase or other any interest in the subject matter of the litigation". In Engiand a barrister mav not agree that fees shall be paid according to the cvent: such an agreement is champertous. However it appears that a solicitor, though he mav nnt bargain for a percentage of the amount recovered, may act for a client on the understanding that his fee will be paid out of the amount tecovered. In the United States agreements for fees based on the amount recovered came to be accepted when personal injury cases became common, for many claimants had no funds. In some Canadian provinces there are provisions in statute or rules of court permitting the solicitor to make a written agreement with his client that the fees shall be based on a percentage of the amount recovered, though in Ontario this is confined to non-contentious matters, and usually the agreement is subject to approval of the court. In at least one province, (Alberta) it is expressiy stated that these agreements do not give validity to a purchase by the lawyer of an interest in the suit or to an agreement that he shall be paid only in the event of success.

Most of the other duties are tradirional ones owed to the client-not to represent conflicting interests. to setrle if postible, and wo keep the client's secrets 
and confidences. Lastly he is obliged to account promptly to his client for moneys received and to keep trust funds separate from his own. In some pro vinces there are elaborate rules to this end. To compensate clients for their loss where the solicitor has falled to accouni, some law sncieties have established an assurancr tund from contributions made by the members.

The iast canon we shall note is one which forbids the solicitation of business. Triough permiting the use of ordinary simple business cards, it deprecates indirect advertising and selfolaudation. There may be details which some soliri. tors include on letterhead, professional cards or "shingles" that would not be approved in England, but generally speaking all these media have been used with restraint and so tar as I know the publication of notices indicating special. ization is disapproved.

The actual ethical standards of the profession cannot. of course, be deter mined by reading ics paper standards but only by knowing the extent to whicl. they are observed.

Having completed our shurt review of the Canadian Canons, we will coll.. clude this paper by a consideration of the question - how best to implant. naintain and strengthen the best traditions of the proiession.

A start should be made with the student entering the law school. Almos: everyone planning to enter the profession in Canada atrends a ian: school after iwo, three or more years of University training. It mav be impossible to ap. praise the character of applicants but rests of aptitude and interest and personal interviews may assist in making selections that will eliminate some who seem ti show lirtle promise.

Then, from the time the student enters law schoul. his instructurs can tcat: him the history of the profession, encourage the reading of biographies of great lawyers and judges, discuss ethical problems as thev arise from time to time. and have him study the canons of ethics. It may be too that a course on the subjec: might be offered as is done in some American schools: certainlv the studv n! one of the good case books or J. G. Brinker's recent cext would be profitabl: firr though they are American they contain English material and as alrcach stated the Canadian canons resemble the American. Manv think that the be'st way to inculeate high standards is to drop the seeds incidentally but it seems reasonable in say that a deliberate and concentrated studv of the subject, aided perhaps by special talks from judges and leaders of the bar, will inevitably give the student a greater awareness of the subject and of its imnortance than he would otherwise receive.

The next step in the training is the period under articles which in most provinces follows law school training though sometimes is contemporaneous with it. It is customary for the Law Society before approval of the articles to require a certificate of character but the writer knows of only one case where an applicant with the requisite educational qualifications was ever refused and that was on the ground that he was a Communist.

During the period of articles the scudent is of course under the rutelage of the practitioner with whom he is articled. One cannot deny the profound in- 
fiuence of a good principal, who really accepts his obligations as a preceptor of his student. Of course if the principal does not himself have eracting standards or does not take the trouble to reach the student or does not have the type of practice that gives the seudent wide experience, then the period of articles may be of little value; but in most instances this is not the case. The Law Socieries could however remind the principal of his obligation to impress on the strudent our ethical standards.

Next comes the ceremony of admission. In most, if not all, provinces the candidate cakes an oath before the presiding Supreme Court justice. In some, the oath is the same as the English solicitors' oath. In several, it is longet, and combines an oach of allegiance with a pledge that in itself is a short code of ethics. Frequently the presiding justice comments on the oath and emphasizes the responsibility and obligations that the new practivioner asumes. After his admission to practice the young lawyer will of course meet ethical problems from time to time: but if he is aware of his obligations and conscientiously ad. dresses himseif to the problem he is unlikely to go far astray.

As long as he is in practice he is of course subject so the disciplinary power of the Benchers of the provincial law society, and may be reprimanded, sus. pended or struck off the rolls. The wise exercise of this power is of the first importance. To adapt tine words of Cockburt C.J., disciplinary bodies can properly say:

We have a ducy to perform to the suitors of the Court, and noe anly to the arivers of the Court but to the profession of the law, by taking care that these perminud op prectice in it spe persons on whoue integrity and honour reliance can be pleced.

in preparing this paper it has not been possible to make an examination into dil the types of compiaints that come before the disciplinary committees. Doubrless these include failing to account for funds, dilatory conduct or neglect in handling of estares, taking collusive divorce actions, and advertising. It is doubtful that there are many complaints for breaches of etiquette in court for che judiciary can douhtless deal effectively with these, if necessary by exercising the power to punish for contempt.

It would be unsafe however to judge the standard of the bas solely or mainly by the number of complaints. The objective should not be merely to keep out of reach of the disciplinary machinery, but should be much higher. A lawver might go through life without ever being the subject of a complaint even though he is one who buys property from his clent at an undervaluacion knowing that he can make a profit, who draws his client's will wich himself as beneficiary. who assises clienes in illegai schernes, who misleads the courr, and who never wbliges his fellow lawyer.

It is not enough to say that the great majority do not act in this mannes, for the public tends to judge the profession by its less worthy members. The principles which the profession in Canada inherits from the mocher country will be secured only if every member of the legal profession remembers that he is in the fiduciary position, an officer of the court, and duty-bound to maintain respect for the law and for the coures, and to aid in the administration of justice. 